\title{
Synthesis of Graphene/ $\mathrm{Cu}_{2} \mathrm{O}$ Thin Film Photoelectrode via Facile Hydrothermal Method for Photoelectrochemical Measurement \\ (Sintesis Fotoelektrod Filem Nipis Grafen/ $\mathrm{Cu}_{2} \mathrm{O}$ melalui Kaedah Hidroterma Tindak Balas Mudah bagi Pengukuran Fotoelektrokimia)
}

\author{
ROSMAHANI MOHD SHAH, ROZAN MOHAMAD YUNUS*, MOHD SHAHBUDIN MASDAR@MASTAR, \\ LORNA JEFFEREY MINGGU, WAI YIN WONG \& ABDUL AMIR H. KADHUM
}

\begin{abstract}
The process of carbon dioxide $\left(\mathrm{CO}_{2}\right)$ reduction by using efficient non-precious-metal catalyst to make the process be economical has brought a comprehensive research in the area. In this study, graphene layer in copper foil was easily synthesized using hydrothermal method at temperature $200^{\circ} \mathrm{C}$ in 3 h duration. Diffraction peaks in XRD at around $29^{\circ}$, $36^{\circ}, 42^{\circ}$ and $74^{\circ}$ in the composites correlate to the (110), (111), (200) and (311) crystalline planes of cubic cuprous oxide $\left(\mathrm{Cu} u_{2} \mathrm{O}\right)$, while peak at $27^{\circ}$ showed the carbon graphitic peak. Raman confirms the presence of the graphene layer on $\mathrm{Cu}_{2} \mathrm{O}$. Photoelectrochemical performance test of Graphene/Cu $\mathrm{O}_{2} \mathrm{O}$ demonstrated that the photoelectrocatalyst showing the photocurrent density $9.6 \mathrm{~mA} \mathrm{~cm}^{-2}$ at $-0.8 \mathrm{~V} v \mathrm{Ag} / \mathrm{AgCl}$. This study demonstrated a potential of semiconductor-based hybrid electrode for an efficient photoelectrocatalytic of $\mathrm{CO}_{2}$ reduction.
\end{abstract}

Keywords: $\mathrm{CO}_{2}$ reduction; cuprous oxide; graphene; photoelectrochemical

ABSTRAK

Proses penurunan karbon dioksida $\left(\mathrm{CO}_{2}\right)$ dengan menggunakan pemangkin bukan logam berharga yang berkesan untuk menghasilkan proses yang lebih berekonomi telah membawa kepada penyelidikan yang komprehensif dalam bidang tersebut. Dalam kajian ini, lapisan grafen pada kerajang tembaga disintesis dengan mudah menggunakan kaedah hidroterma pada suhu $200^{\circ} \mathrm{C}$ dalam tempoh masa 3 jam. Puncak belauan XRD pada sudut $29^{\circ}, 36^{\circ}, 42^{\circ}$ dan $74^{\circ}$ menunjukkan satah hablur kubik oksida $\left(\mathrm{Cu}_{2} \mathrm{O}\right)(110),(111),(200)$ dan (311) dan puncak grafit karbon ditunjukkan pada sudut $27^{\circ}$. Raman mengesahkan kehadiran lapisan grafen pada $\mathrm{Cu}_{2} \mathrm{O}$. Ujian prestasi fotopemangkinan grafen/ $\mathrm{Cu}_{2} \mathrm{O}$ menunjukkan bahawa fotomangkin tersebut mempunyai ketumpatan fotokimia $9.6 \mathrm{~mA} \mathrm{~cm}^{-2} \mathrm{pada}-0.8 \mathrm{~V} \mathrm{vs} \mathrm{Ag} /$ $\mathrm{AgCl}$. Kajian ini menyumbang kepada penghasilan elektrod hibrid berasaskan semikonduktor sebagai fotomangkin yang berkesan untuk penurunan $\mathrm{CO}_{2}$.

Kata kunci: Fotoelektrokimia; grafen; kuprus oksida; penurunan $\mathrm{CO}_{2}$

\section{INTRODUCTION}

Global warming that cause by increasing green house gases and inadequacy of energy are two critical issues of this century. Heating caused by increased carbon dioxide $\left(\mathrm{CO}_{2}\right)$ is an important issue that can be addressed through the process of reducing $\mathrm{CO}_{2}$ to produce certain sources of chemicals and fuels (Nor et al. 2017). At the same time, the production of carbon-based products through the reduction process can be generated to assist in the generation of useful energy (Wui Fui et al. 2019). Reduced $\mathrm{CO}_{2}$ by photocatalytic methods is increasingly gaining attention as this approach can change $\mathrm{CO}_{2}$ into hydrocarbon fuels such as alcohols, carbon monoxide and other gas and liquid products (Jiang et al. 2010).

Cuprous oxide $\left(\mathrm{Cu}_{2} \mathrm{O}\right)$, with a direct band gap $(2.0 \mathrm{eV})$ also have a rare green characteristics, such as non-toxicity and compatibility with environment. The promising band gap and relevant arrangement of the conduction and valence bands, make it an excellent photocatalyst for $\mathrm{CO}_{2}$ photoreduction (An et al. 2014). $\mathrm{Cu}_{2} \mathrm{O}$ has been used for the photoconversion of $\mathrm{CO}_{2}$ into $\mathrm{CO}$, which is a profitable chemical for assorted synthetic reactions (Fischer-Tropsch synthesis) and important fuel for generation of energy. In term of photocurrent density, the photoelectrochemical (PEC) measurement of $\mathrm{Cu}_{2} \mathrm{O}$ nanowire under $100 \mathrm{~mW} \mathrm{~cm}^{-2}$ light irradiation and $0.5 \mathrm{M} \mathrm{Na}_{2} \mathrm{SO}_{4}$ electrolyte solution, has generated $-5.45 \mathrm{~mA} \mathrm{~cm}^{-2}$ at $-0.6 \mathrm{~V}$ vs. $\mathrm{Ag} / \mathrm{AgCl}$ due to low charge transfer resistant under illumination (Nur et al. 2018). However, the stability of $\mathrm{Cu}_{2} \mathrm{O}$ is a crucial issue as the redox potentials for the reduction and oxidation of monovalent copper oxide lie within the band gap (Qiao et al. 2014). Carbonaceous nanomaterials have been utilized broadly to enhance the performance of photocatalysts due to their promising electronic and catalytic properties. For example, the photostability and photocurrent density of $\mathrm{Cu}_{2} \mathrm{O}$ nanowire arrays could notable increase with the existence of a thin protective carbon layer ( $\mathrm{Zhu}$ et al. 2014). 
The $\mathrm{sp}^{2}$ hybridized carbon atoms, graphene, a two dimensional monolayer, has draw attention in recent years because of its attractive physical and chemical properties (Geim \& Novoselov 2009). In general, graphene is a zero band gap semiconductor with asymmetric band structure. The unique band structure gives graphene impressive conductivity and electron mobility characteristic (Patten et al. 2016). Graphene can act as a great electrical conductivity material to expedite the charge separation and transfer. Through its unique electron collecting and transfer potential, the use of graphene could make the multi-electron reduction process of $\mathrm{CO}_{2}$ more productive and stimulate the selective production of paticular fuels in photocatalytic $\mathrm{CO}_{2}$ reduction ( $\mathrm{Li}$ et al. 2016). In addition, graphene can operate as a co-catalyst reinstate noble metals for solar fuel generation to expedite the redox reaction ( $\mathrm{Li}$ et al. 2017). Graphene oxide (GO) is a singleatomic layered material, which is prepared by oxidation and exfoliation of graphite by having the alteration of the basal plane. GO is laced with oxygen-containing groups, reported to have limited electrical transport and conductivity due to the oxygen functionalization on the basal plane surface (Dave et al. 2016). The advantage of reduced graphene oxide ( $\mathrm{rGO}$ ) is the material is almost identical in structure to pristine graphene and most importantly it is conductive material which may increase the electrical conductivity of the composite (Ong et al. 2015).

Hydrothermal synthesis is refers to a method of fabricate materials, above ambient temperature and pressure especially for metal oxides or sulfates via chemical reactions. The way to synthesize materials are similar to some precious crystals such as quartz crystal which formed in our earth. In the artificial hydrothermal synthesis, a sealed solution in apparatus was heat above ambient temperature and pressure. Hydrothermal condition is a promising method to crystallized material in a controllable atmosphere. Performing under mild operating conditions (reaction temperatures $<300^{\circ} \mathrm{C}$ ), hydrothermal synthesis is also a facile method which is one-step synthetic procedure and economically which is inexpensive of instrumentation including energy precursors compared with other solution synthesis method (Somiya \& Roy 2000).

Herein, with a beneficial combination of $\mathrm{Cu}_{2} \mathrm{O}$ and graphene, $\mathrm{Cu}_{2} \mathrm{O}$ and reduced graphene oxide composites were synthesis facilely via chemical reaction in hydrothermal reactor. The formation of $\mathrm{Cu}_{2} \mathrm{O}$ which act as a photoactive film (Kubacka et al. 2012) and the reduction of $\mathrm{GO}$ took place in reaction to form $\mathrm{Cu}_{2} \mathrm{O}$ covered with reduced graphene oxide (RGO) sheets. RGO act as an excellent electron trapper to prevent fast charge recombination (Lv et al. 2013) and subsequencely increase the photocurrent density of the material. With high photocurrent density, production rate of valuable product will be increase accordingly which could be attractive as visible-light-driven $\mathrm{CO}_{2}$ reduction catalysts (Kalamaras et al. 2018).

\section{MATERIALS AND METHODS}

\section{PREPARATION OF $\mathrm{CU}_{2} \mathrm{O}$ /GRAPHENE COMPOSITES ON} COPPER SHEETS FOR HYDROTHERMAL REACTION

Pure copper substrates thickness $0.25 \mathrm{~mm}, 99.99 \%$ trace metal basis (Sigma-Aldrich) were polished with 150 Grit sand paper followed by cleaning with acetone from R\&M Chemical and ethanol from QRec, then ultrasound bath for $10 \mathrm{~min}$ to remove the surface impurities. About $10 \mathrm{mg}$ Graphene Oxide (GO) powder were purchased from SigmaAldrich was dispersed in $10 \mathrm{~mL} \mathrm{~N}, \mathrm{~N}$ dimethylformamide (DMF) from Merck as dissolved solvent and sonicated for $10 \mathrm{~min}$. The $0.1 \mathrm{~mL}$ hydrazine monohydrate $\left(\mathrm{N}_{2} \mathrm{H}_{4} \cdot \mathrm{H}_{2} \mathrm{O}\right)$ reagent grade $98 \%$ were purchased from Sigma-Aldrich was added as a reduction agent for another $30 \mathrm{~min}$. Cleaned copper foil substrates $\left(3.0 \times 1.5 \mathrm{~cm}^{2}\right)$ were place into the above GO solution, then the mixture is inserted into a $50 \mathrm{~mL}$ Teflon-lined stainless-steel autoclave, purged with nitrogen gas $\left(\mathrm{N}_{2}\right)$ for $20 \mathrm{~min}$ to remove evolved gases. There are two samples prepared in each hydrothermal reaction for measurement in dark and light environment during PEC testing. After the hydrothermal reaction at temperature $200^{\circ} \mathrm{C}$ for three different condition $(1,3$ and $6 \mathrm{~h}$ ), the final product is moisture out in ambient environment.

\section{CHARACTERISATIONS}

The X-ray diffraction (XRD) patterns are carried out using a diffractometer (Bruker D8 Advance) with $\mathrm{CuK} \alpha$ radiation. The morphology is characterized using fieldemission scanning electron microscope (FESEM) (Zeiss AM10). Intrinsic properties of the samples are measured with Raman micro imaging microscopy (Thermo Scientific DXR2xi).

\section{PHOTOELECTROCHEMICAL (PEC) MEASUREMENTS}

$\mathrm{Cu}_{2} \mathrm{O} /$ Graphene composite with an area of $1.5 \times 1.5 \mathrm{~cm}^{2}$ is deposited on copper foil as a conductive substrate is used as working electrode. The neutral electrolyte used is $0.5 \mathrm{M}$ Sodium Sulfate $\left(\mathrm{Na}_{2} \mathrm{SO}_{4}\right)$ aqueous solution which purged with inert gas for $10 \mathrm{~min}$ prior measurement. Three-electrode cells were assemble subsists of collected samples as working electrode, platinum wire as a counter electrode and a reference saturated $\mathrm{Ag} / \mathrm{AgCl}$. To execute a photocurrent measurement, the electrodes in PEC cell are attached to the respective cable leads of the Ametek Versastat 4, using linear sweep voltammetry (LSV) function with scan rate of 0.05 $\mathrm{V} \mathrm{s}-1$. The samples are determined under a dark and light environment under $100 \mathrm{~mW} \mathrm{~cm} \mathrm{~cm}^{-2}$ xenon light irradiation. For each condition of light on and light off, 3 samples are tested before the average data was collected where the $\mathrm{Cu}_{2} \mathrm{O}$ film/ $\mathrm{Cu}$ is prepared as the controlled sample.

\section{RESULTS AND DISCUSSION}

The catalyst was fabricated easily by hybridizing graphene layered on copper foil in a facile hydrothermal reaction 
(Figure 1). During thermal heating in the autoclave, the graphene oxide ( $\mathrm{GO}$ ) were reduced by hydrazine mohohydrate $\left(\mathrm{N}_{2} \mathrm{H}_{4}\right)$, which its role as chemical reductants in the reaction. GO surface is attached with various oxygen-containing groups, predominantly hydroxyl $(-\mathrm{OH})$ or carboxyl $(-\mathrm{COOH})$ which increases the GO hydrophobicity. When GO reacts with hydrazine as a reductant, the number of functional groups will subsequently decrease leads to the formation of rGO (Pan et al. 2013). The detached -OH group may react with copper ion to produce copper hydroxide $\left(\mathrm{Cu}(\mathrm{OH})_{2}\right)$, then $\mathrm{Cu}(\mathrm{OH})_{2}$ will further react with $\mathrm{N}_{2} \mathrm{H}_{4}$ to produce $\mathrm{Cu}_{2} \mathrm{O}$. Suspected graphene layer which will be confirm by Raman were uniformly grown in situ on the surface of the copper foil, at the same time. After the hydrothermal process, the hybrid composite was dried to removed the residue. In the process, $\mathrm{Cu}_{2} \mathrm{O}$ was grown on the copper foil, then graphene oxide was deposited on the $\mathrm{Cu}_{2} \mathrm{O}$ layer. There are two significant advantages for this fabrication: The procedure is facile, which is only four materials was used in $3 \mathrm{~h}$ time fabrication compared to other fabrication methods and more importantly, the copper foil can directly use as electrode in photoelectrochemical cell without further step of preparation.
Figure 2(a) and 2(b) shows the optical microscope and photos of three different samples collected after hydrothermal in different growth duration times which is 1,3 and $6 \mathrm{~h}$. It has been found that the sample in 1 $\mathrm{h}$ hydrothermal reaction time as shown in Figure $2 b(\mathrm{i})$, exhibits poor coverage area of graphene on $\mathrm{Cu}_{2} \mathrm{O}$ while the sample in $6 \mathrm{~h}$ (Figure $2 \mathrm{~b}$ (iii)) was peel off as indicated by the arrow and due to the thickness issue. Therefore, it is not suitable for further photoelectrochemical analysis. By increasing the growth duration, the layer of rGO on $\mathrm{Cu}_{2} \mathrm{O}$ films was became thicker. Meanwhile, sample in 3 $\mathrm{h}$ hydrothermal growth time (Figure $2 \mathrm{~b}(\mathrm{ii})$ ) is selected for further analysis due to the uniformly full coverage area of graphene on the copper foil. It can be concluded that the hydrothermal growth duration time has influenced the coverage area and thickness of the rGO deposition on the $\mathrm{Cu}_{2} \mathrm{O}$ film and sample in $3 \mathrm{~h}$ growth duration was found as the optimal duration time for further measurement.

Raman spectroscopy is widely used to identify the number of layers, defects in rGO, and also the tools for the characterazation properties of carbon materials (Wu et al. 2018). Figure 2(a) shows the optical microscope images of three samples in different hours of hydrothermal which is 1,3 and $6 \mathrm{~h}$. Increasing the growth duration contribute

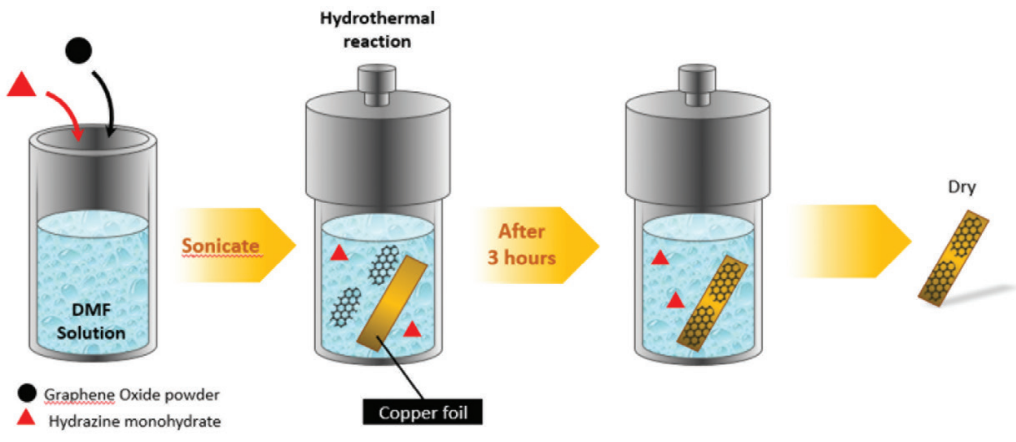

FIGURE 1. Fabrication process of $\mathrm{rGO} / \mathrm{Cu}_{2} \mathrm{O}$ composite through facile hydrothermal method

(a)

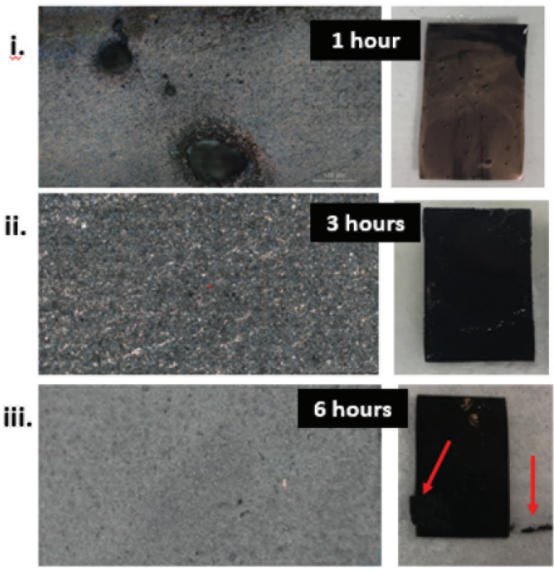

(b)

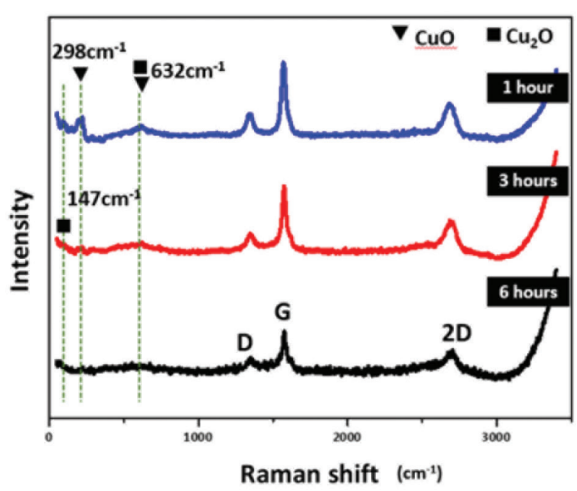

FIGURE 2. Raman analysis for differents hydrothermal hours (a) Optical microscope image of $\mathrm{rGO} / \mathrm{Cu}_{2} \mathrm{O}$ layer on copper foil, (b) Photos of thin film after hydrothermal reaction, and

(c) Raman shift of $\mathrm{rGO} / \mathrm{Cu}_{2} \mathrm{O}$ 
to the uniformity surface layer obtained above the copper foil. In order to further investigate the reduction of $\mathrm{GO}$ and formation of $\mathrm{Cu}_{2} \mathrm{O}$ during hydrothermal treatment, Raman spectroscopy was used to characterize these samples. Theoretically, Raman peaks at $147 \mathrm{~cm}^{-1}$ is a signal correspond to $\mathrm{Cu}_{2} \mathrm{O}$, whereas the peaks at $298 \mathrm{~cm}^{-1}$ is a signal of $\mathrm{CuO}$, while the peak at $632 \mathrm{~cm}^{-1}$ is reported the formation of both $\mathrm{CuO}$ and $\mathrm{Cu}_{2} \mathrm{O}$ (Gusain et al. 2016). From the observed Raman signals of sample in $1 \mathrm{~h}$ hydrothermal reaction time, the broad peak of cupric oxide $(\mathrm{CuO})$ at 298 $\mathrm{cm}^{-1}$ and $632 \mathrm{~cm}^{-1}$ confirmed that $\mathrm{CuO}$ not fully transformed to $\mathrm{Cu}_{2} \mathrm{O}$ due to limitation of reaction hours. While Raman peaks of $\mathrm{Cu}_{2} \mathrm{O}$ in sample in $6 \mathrm{~h}$ hydrothermal reaction were not observed because the $\mathrm{Cu}_{2} \mathrm{O}$ layer is well covered by the rGO. This observation showed that the higher the reaction time, peak of $\mathrm{Cu}_{2} \mathrm{O}$ will not be observed in the Raman spectrum. Therefore, the intermediate hours of $3 \mathrm{~h}$ was selected due to the uniformity of graphene layer over the copper foil and also considering the optimum hours for $\mathrm{CuO}$ to transform to $\mathrm{Cu}_{2} \mathrm{O}$. The Raman spectrum of $\mathrm{GO}$ has been used to compare the degree of defects in RGO. The ID/IG ratio increases from 1.08 in GO to 1.5 in RGO, which is attributed to the removal of oxygen functional groups and the defect densities formed in the rGO.

The ratio of the $\mathrm{D}$ band $\left(1,350 \mathrm{~cm}^{-1}\right)$, commenced from disorder-activated Raman mode, to the $\mathrm{G}$ band (1,596 $\mathrm{cm}^{-1}$ ), corresponding to $\mathrm{sp}^{2}$ hybridized carbon, is used to regulate the expansion of reduction (Pei \& Cheng 2012). $\mathrm{D} / \mathrm{G}$ ratio for 1 and $3 \mathrm{~h}$ sample in hydrothermal is 0.31 each and 0.40 for sample in $6 \mathrm{~h}$ hydrothermal reaction. The slight increase in the $\mathrm{D} / \mathrm{G}$ ratio for samples in 1 and 3 $\mathrm{h}$ hydrothermal reaction and sample in $6 \mathrm{~h}$ hydrothermal reaction from 0.31 to 0.40 suggests a decrease in the average size of the $\mathrm{sp}^{2}$ domains upon reduction. This imply that rGO has a small size and a large quantity of edges, which act as defects and influence to the increase in the D band. In addition, the peak at $2,694 \mathrm{~cm}^{-1}$, interrelated to the $2 \mathrm{D}$ band which demonstrate the multilayer structure of rGO in the composites.

Figure 3 shows the X-ray diffraction (XRD) result of the $\mathrm{Cu}$ foil substrates and GO powder prepared by the hydrothermal method at 200 for $3 \mathrm{~h}$. All the diffraction peaks in the XRD patterns of samples match well with those of cubic-phase $\mathrm{Cu}_{2} \mathrm{O}$ (JCPDS No.78-2076). Three peaks centered in XRD result at $43^{\circ}, 50^{\circ}$, and $73^{\circ}$, refer to the (111), (200), and (220) planes of metallic copper (Fan \& Wu 2016), can be clearly observed, which suggest that the $\mathrm{Cu}$ foil substrates were not fully utilized in these samples, meaning that there is still copper which not yet transformed to $\mathrm{Cu}_{2} \mathrm{O}$. Four new characteristic diffraction peaks at $29^{\circ}$, $36^{\circ}, 42^{\circ}$, and $74^{\circ}$ in the composites correspond to the (110), (111), (200) and (311) crystalline planes of cubic $\mathrm{Cu}_{2} \mathrm{O}$ (de Brito et al. 2015)ethanol, formaldehyde, acetaldehyde, and acetone was monitored during UV-visible radiation for $3 \mathrm{~h}$ at $+0.20 \mathrm{~V}$ (vs. $\mathrm{Ag} / \mathrm{AgCl}$ reference (Figure 3(a)). The existance of carbon spesies diffraction peaks at $2 \theta=27^{\circ}$, correspond to the presence of graphitic carbon in the composites which confirmed by Raman characterization in Figure 2, that is rGO.

The microstructure and elemental composition of the sample in $3 \mathrm{~h}$ growth duration were observed by FESEM and EDX. The FESEM image (Figure 4) reveals the formation of graphene layer deposited on the $\mathrm{Cu}_{2} \mathrm{O}$ layer, which transformed from the copper foil. The FESEM crosssectional image as seen in Figure 4(c) shows the thickness of the composites layer is about $6.1 \mu \mathrm{m}$. While the EDX composition of each elements are $58 \%$ of carbon (red color in figure 4(b)), 39.6\% of copper (green color in Figure 4(b)) and $2.4 \%$ contain of oxygen (blue color in Figure $4(\mathrm{~b})$ ), implying the formation of $\mathrm{rGO} / \mathrm{Cu}_{2} \mathrm{O}$ nanocomposites.

To investigate the role of graphene $(G)$ on the segregation and transport of photogenerated charge carriers, the sample directly used to execute photocurrent measurements. The rapid and replicable photocurrent

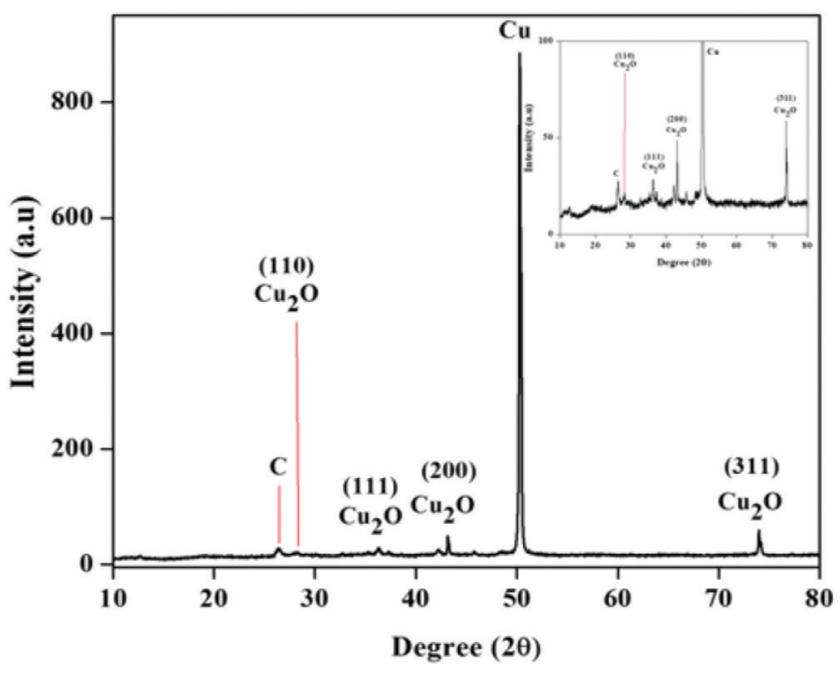

FIGURE 3. Analysis for $\mathrm{rGO} / \mathrm{Cu}_{2} \mathrm{O}$ in $3 \mathrm{~h}$ hydrothermal reaction. XRD patterns with inset of high resolution of $\mathrm{Cu}_{2} \mathrm{O}$ peak 
(a)

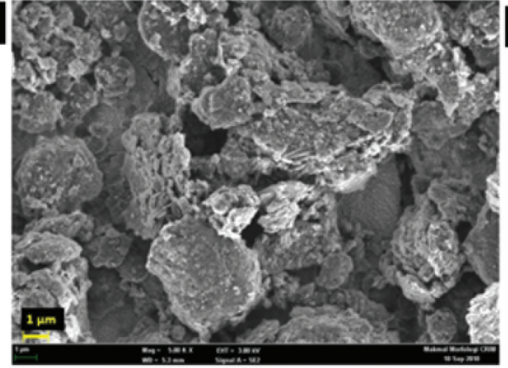

(b)

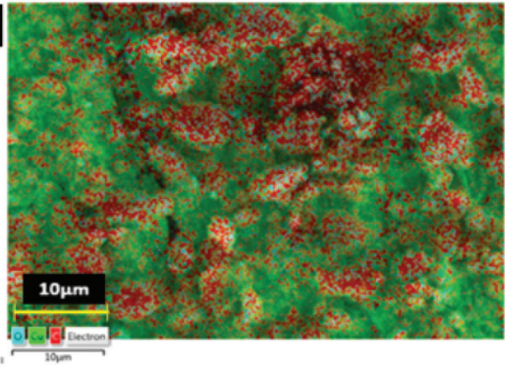

$(c)$

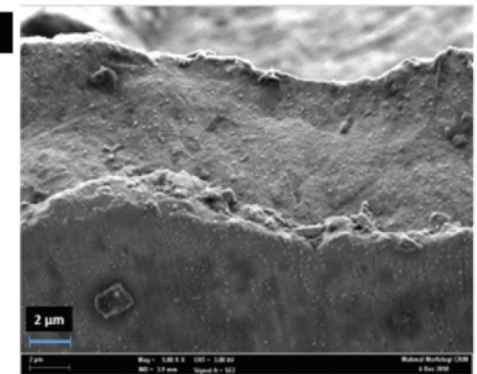

(d)

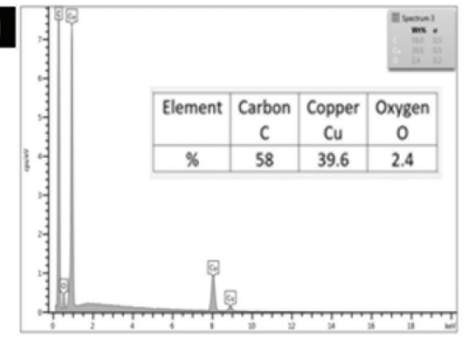

FIGURE 4. Analysis for $\mathrm{rGO} / \mathrm{Cu}_{2} \mathrm{O}$ in $3 \mathrm{~h}$ hydrothermal reaction (a) FESEM image, (b) EDX mapping, (c) Cross sectional layer, and (d) EDX elemental composition

response for each light-on and light-off light cycle p-type $\mathrm{Cu}_{2} \mathrm{O} / \mathrm{rGO}$ electrodes is demonstrate in Figure 5. Under simulated solar light ilumination power density of $100 \mathrm{~mW}$ $\mathrm{cm}^{-2}$ using Xenon lamp as a light source, the photocurrent density of the $\mathrm{Cu}_{2} \mathrm{O} / \mathrm{G}$ electrode was read at $9.6 \mathrm{~mA} \mathrm{~cm}^{-2}$ at $-0.8 \mathrm{~V}$ vs Ag/AgCl. Meanwhile, Salehmin et al. (2018) reported the photocurrent for $\mathrm{Cu}_{2} \mathrm{O}$ nanowire (NW) was achieved at $5.45 \mathrm{~mA} \mathrm{~cm}^{-2}$ at $0 \mathrm{~V}$ vs $\mathrm{Ag} / \mathrm{AgCl}$ through two step synthesis method which involved fabrication of $\mathrm{Cu}(\mathrm{OH})_{2}$ NW then transformation of $\mathrm{Cu}(\mathrm{OH})_{2} \mathrm{NW}$ to $\mathrm{Cu}_{2} \mathrm{O} \mathrm{NW}$. In the fabrication, $\mathrm{CU}_{2} \mathrm{O} \mathrm{NW}$ was obtained through annealing in $\mathrm{N}_{2}$ flow at $500^{\circ} \mathrm{C}$ for $2 \mathrm{~h}$ (Salehmin et al. 2018). The high photocurrent achieved is due to NW structure has shorter travel distance to reach the interface and the larger photoelectrocatalytic active area will give the better light entrapment to the material. In our work,

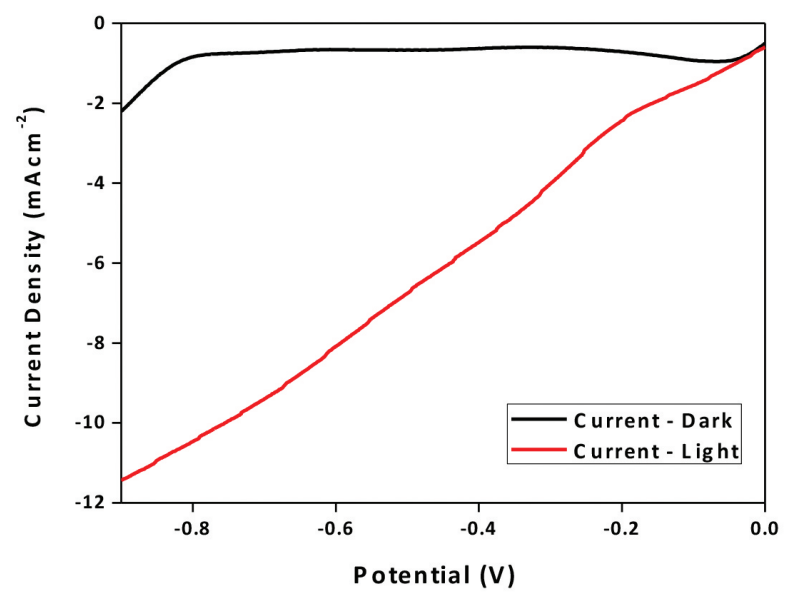

FIGURE 5. PEC data of linear sweep voltammetry (LSV) plot of $\mathrm{Cu}_{2} \mathrm{O} / \mathrm{rGO}$ in $3 \mathrm{~h}$ hydrothermal condition after depositing an rGO layer on top of the $\mathrm{Cu}_{2} \mathrm{O}, \mathrm{Cu}_{2} \mathrm{O}$ emerge through the $\mathrm{rGO}$ surface, forming $\mathrm{Cu}_{2} \mathrm{O} / \mathrm{rGO}$ composites. The expected mechanism is $\mathrm{rGO}$ acts as an electron acceptor to extract photogenerated electrons from $\mathrm{Cu}_{2} \mathrm{O}$, resulting in efficient charge separation within the semiconductor, and improving the photocurrent. The enhancement of photocurrent clearly indicates that $\mathrm{rGO}$ acts as a good electron acceptor, helping to enhance charge separation within the $\mathrm{p}-\mathrm{Cu}_{2} \mathrm{O}$ semiconductor. In addition, production rate of product is related to the current density (Kalamaras et al. 2018). From this research, with the high achievement on photocurrent density, the catalyst expected to become the promising material in $\mathrm{CO}_{2}$ reduction because increasing the reaction rate will increase apparently the production of the valuable product.

\section{CONCLUSION}

In summary, we have described a facile hydrothermal method to prepare $\mathrm{Cu}_{2} \mathrm{O} / \mathrm{G}$ composite films on the surface of copper foil substrates over an in situ redox reaction between the GO and the $\mathrm{Cu}$ foil. Photoelectrochemical performance test demonstrated that the photoelectrocatalyst showing the photocurrent density $9.6 \mathrm{~mA} \mathrm{~cm}^{-2}$ at $-0.8 \mathrm{~V}$ vs $\mathrm{Ag} / \mathrm{AgCl}$ which is about 4.5 times higher in light compared to dark condition. The simple and economical fabrication make the $\mathrm{Cu}_{2} \mathrm{O} / \mathrm{Graphene}$ composite evolve in this study a very promising catalyst for the competent photoelectrochemical conversion of $\mathrm{CO}_{2}$ to profitable fuels.

\section{ACKNOWLEDGEMENTS}

The authors would like to acknowledge technical and management support from Research and Instrumentation Management Center (CRIM), Universiti Kebangsaan 
Malaysia. The authors also gratefully acknowledge the financial support given for this work by Malaysia Research University Grant, GUP-2018-014 and DIP-2016-020.

\section{REFERENCES}

An, X., Li, K. \& Tang, J. 2014. $\mathrm{Cu}_{2} \mathrm{O} /$ reduced graphene oxide composites for the photocatalytic conversion of $\mathrm{CO}_{2}$. ChemSusChem 7(4): 1086-1093.

Dave, S.H., Gong, C., Robertson, A.W., Warner, J.H. \& Grossman, C. 2016. Chemistry and structure of graphene oxide via direct imaging. ACS Nano 10(8): 7515-7522.

de Brito, J.F., Araujo, A.R., Rajeshwar, K. \& Zanoni, M.V.B. 2015. Photoelectrochemical reduction of $\mathrm{CO}_{2}$ on $\mathrm{Cu} /$ $\mathrm{Cu}_{2} \mathrm{O}$ films: Product distribution and $\mathrm{pH}$ effects. Chemical Engineering Journal 264: 302-309.

Fan, Y.J. \& Wu, S.F. 2016. A graphene-supported copper-based catalyst for the hydrogenation of carbon dioxide to form methanol. Journal of $\mathrm{CO}$, Utilization 16: 150-156.

Geim, A.K. \& Novoselov, K.S. 2009. The rise of graphene. Nature Materials 6(11-19): 183-191.

Gusain, R., Kumar, P., Sharma, O.P., Jain, S.L. \& Khatri, O.P. 2016. Reduced graphene oxide- $\mathrm{CuO}$ nanocomposites for photocatalytic conversion of $\mathrm{CO}$ into methanol under visible light irradiation. Applied Catalysis B: Environmental 181: 352-362.

Jiang,Z., Xiao, T., Kuznetsov, V.L. \& Edwards, P.P. 2010. Turning carbon dioxide into fuel. Philosophical Transactions of the Royal Society A: Mathematical, Physical and Engineering Sciences 368(1923): 3343-3364.

Kalamaras, E., Maroto-Valer, M.M., Shao, M., Xuan, J. \& Wang, H. 2018. Solar carbon fuel via photoelectrochemistry. Catalysis Today 317: 56-75.

Li, X., Yu, J., Wageh, S., Al-Ghamdi, A.A. \& Xie, J. 2016. Graphene in photocatalysis: A review. Small 12(48): 66406696.

Li, Z., Pi, Y., Xu, D., Li, Y., Peng, W., Zhang, G., Zhang, F. \& Fan, X. 2017. Utilization of $\mathrm{MoS}_{2}$ and graphene to enhance the photocatalytic activity of $\mathrm{Cu}_{2} \mathrm{O}$ for oxidative $\mathrm{C}-\mathrm{C}$ bond formation. Applied Catalysis B: Environmental 213: 1-8.

Nor Lailatul Wahidah, M., Wan Juliana, W.A., Nizam, M.S. \& Che Radziah, C.M.Z. 2017. Effects of elevated atmospheric $\mathrm{CO}_{2}$ on photosynthesis, growth and biomass in Shorea platycarpa F. Heim (Meranti Paya). Sains Malaysiana 46(9): 1421-1428.

Nur, M., Salehmin, I., Je, L., Mark-Lee, W.F., Azuwa, M., Ari, K., Ha, M., Jumali, H. \& Kassim, M.B. 2018. Solar energy materials and solar cells highly photoactive $\mathrm{Cu}_{2} \mathrm{O}$ nanowire film prepared with modified scalable synthesis method for enhanced photoelectrochemical performance. Solar Energy Materials and Solar Cells 182(3): 237-245.

Ong, W.J., Tan, L.L., Chai, S.P. \& Yong, S.T. 2015. Graphene oxide as a structure-directing agent for the two-dimensional interface engineering of sandwich-like graphene-g$\mathrm{C}_{3} \mathrm{~N}_{4}$ hybrid nanostructures with enhanced visible-light photoreduction of $\mathrm{CO}_{2}$ to methane. Chem. Commun. 51(5): 858-861.
Pan, X., Zhao, Y., Wang, S. \& Fan, Z. 2013. TiO/graphene nanocomposite for photocatalytic application. Materials and Processes for Energy: Communicating Current Research and Technological Developments. pp. 913-920.

Patten, H.V., Velický, M. \& Dryfe, R.A.W.W. 2016. Electrochemistry of graphene. Advances in Electrochemical Science and Engineering 16: 121-161.

Pei, S. \& Cheng, H.M. 2012. The reduction of graphene oxide. Carbon 50(9): 3210-3228.

Qiao, J., Liu, Y., Hong, F. \& Zhang, J. 2014. A review of catalysts for the electroreduction of carbon dioxide to produce lowcarbon fuels. Chem. Soc. Rev. 43: 631-675.

Somiya, S. \& Roy, R. 2000. Hydrothermal synthesis of fine oxide powders. Bulletin of Materials Science 23(6): 453-460.

Wu, J., Bin Lin, M.L., Cong, X., Liu, H.N. \& Tan, P.H. 2018. Raman spectroscopy of graphene-based materials and its applications in related devices. Chemical Society Reviews 47(5): 1822-1873.

Wui Fui, M.L., Yan Yi, C., Kung, P.L. \& Ishak, M.K. 2019 Synthesis, structure and density functional theory (DFT) study of a rhenium (I) pyridylpyrazol complex as a potential photocatalyst for $\mathrm{CO}_{2}$ reduction. Sains Malaysiana 47(7): 1491-1499.

Zhu, W., Zhang, Y.J., Zhang, H., Lv, H., Li, Q., Michalsky, R., Peterson, A.A. \& Sun, S. 2014. Active and selective conversion of $\mathrm{CO}_{2}$ to $\mathrm{CO}$ on ultrathin Au nanowires. Journal of the American Chemical Society 136(46): 16132-16135.

Rosmahani Mohd Shah, Mohd Shahbudin Masdar@Mastar \& Abdul Amir H. Kadhum

Research Centre for Sustainable Process Technology

Faculty of Engineering \& Built Environment

Universiti Kebangsaan Malaysia

43600 UKM Bangi, Selangor Darul Ehsan

Malaysia

Rozan Mohamad Yunus*, Mohd Shahbudin Masdar@Mastar, Lorna Jefferey Minggu \& Wai Yin Wong

Fuel Cell Institute

Universiti Kebangsaan Malaysia

43600 UKM Bangi, Selangor Darul Ehsan

Malaysia

*Corresponding author; email: rozanyunus@ukm.edu.my

Received: 21 November 2018

Accepted: 1 March 2019 